Sains Malaysiana 50(5)(2021): 1255-1265

http://doi.org/10.17576/jsm-2021-5005-06

\title{
Herbicide Atrazine Alters the Microbiota of the Filamentous Green Alga Cladophora sp. Cultured from Thailand
}

(Herbisid Atrazin Mengubah Mikrobiota Alga Hijau Berfilamen Cladophora sp. yang Dikultur dari Thailand)

\author{
Anchittha SatjaraK*, Jittra Piapukiew, Wikrom Chanthapatchot, Karnjana Ruen-Pham \& Alisa S. \\ VANGNAI
}

\section{ABSTRACT}

The attached green alga Cladophora known to harbor microbiota that play important roles in ecosystem, is one of the most common freshwater filamentous green algae in rivers globally, including those in the northern part of Thailand. These rivers mostly run through agricultural regions where herbicides are heavily used to improve crop quality and quantity. The extensively-used herbicide atrazine persists in soil sediments through transport by surface runoff to rivers. The effect of such herbicide contamination on Cladophora microbiota in Thailand have not been investigated. To acquire this information, $16 \mathrm{~S}$ rDNA amplicons were used to compare microbiota of Cladophora sp. cultures treated with a spectrum of atrazine concentrations. The results showed that the Cladophora microbiome included at least 106 possible Operational taxonomic units (OTUs) representing twelve bacterial phyla which are Acidobacteria, Actinobacteria, Armatimonadetes, Chloroflexi, Cyanobacteria, Deinococcus-Thermus, Epsilonbacteraeota, Nitrospirae, Patescibacteria, Planctomycetes, Proteobacteria, and WPS-2, representing both core and local algal bacteria. The presence of atrazine was also correlated with changes in richness of bacterial taxa suggesting that these algal epibiotic bacteria were differently affected by atrazine treatments.

Keywords: 16 S rDNA amplicons; atrazine; Cladophora; microbiomes

\section{ABSTRAK}

Alga hijau Cladophora telah diketahui melindungi mikrobiota yang memainkan peranan penting dalam ekosistem, ia adalah salah satu alga hijau filamen air tawar yang biasa dijumpai dalam sungai di seluruh dunia, termasuk di bahagian utara Thailand. Sungai ini kebanyakannya merentasi kawasan pertanian di mana herbisid banyak digunakan untuk meningkatkan kualiti dan kuantiti tanaman. Herbisid atrazin yang digunakan secara meluas kekal di dalam endapan tanah secara pengangkutan melalui larian permukaan ke sungai. Kesan pencemaran herbisid ke atas mikrobiota Cladophora di Thailand masih belum pernah dijalankan. Untuk memperoleh maklumat ini, amplikon 16SrDNA digunakan untuk membandingkan kultur mikrobiota Cladophora sp. yang dirawat dengan spektrum kepekatan atrazin. Hasil kajian menunjukkan bahawa mikrobiom Cladophora merangkumi sekurang-kurangnya 106 kemungkinan unit operasi taksonomi (OUT) yang mewakili dua belas filum bakteria seperti Acidobacteria, Actinobacteria, Armatimonadetes, Chloroflexi, Cyanobacteria, Deinococcus-Thermus, Epsilonbacteraeota, Nitrospirae, Patescibacteria, Planctomycetes, Proteobacteria dan WPS-2, yang mewakili kedua-dua bakteria alga teras dan tempatan. Kehadiran atrazin juga turut dikaitkan dengan perubahan kekayaan taksa bakteria yang mencadangkan bahawa bakteria epibiotik alga ini dipengaruhi secara berbeza oleh rawatan atrazin.

Kata kunci: Amplikon 16S rDNA; atrazin; Cladophora; mikrobiom

\section{INTRODUCTION}

The green algal genus Cladophora, which is known to play important ecological roles, is common in freshwaters globally (Zulkifly et al. 2013). Cladophora has been documented to occur in the northern and the northeastern part of Thailand, where it forms conspicuous green masses or streamers $10 \mathrm{~cm}$ or longer along the shoreline of main rivers (Laungsuwon \& Chulalaksananukul 2013; Peerapornpisal et al. 2006; Thiamdao et al. 2012). Resistant to grazers, Cladophora provides habitats for other 
organisms, including biofilms of bacteria that may play important functional roles (Braus et al. 2017; Graham et al. 2015; Zulkifly et al. 2012).

To date, many studies of epiphytic microbes of Cladophora have focused on large lakes of the northern United States of America (U.S.A.) (Braus et al. 2017; Byappanahalli et al. 2009, 2007, 2003; Chun et al. 2013; Graham et al. 2015; Ishii et al. 2006; Olapade et al. 2006; Whitman et al. 2003; Zulkifly et al. 2012). These studies showed that Cladophora typically supports surface biofilms that include diverse bacterial and eukaryotic lineages, those of more restricted occurrence representing local taxa and those of broad occurrence representing a core microbiota that may provide key functions in algal growth. For example, Cladophora epibiotic bacteria have been hypothesized to provide many important functions such as nitrogen fixation and providing vitamin B12, which is required for Cladophora growth (Graham et al. 2015).

In Thailand, Cladophora is commonly present in rivers running through agricultural areas where herbicides are heavily used to improve crop quality and quantity. Atrazine (6-chloro-N2-ethyl-N4-isopropyl-1,3,5triazine-2,4- diamine) is one of the top ten herbicides used in the country (Department of Agriculture 2019; EPA 2003). This herbicide is extensively used for preemergence and post-emergence weed controls in corn, sorghum, pineapple, sugarcane, and rice farming (EPA 2003). However, atrazine can persist long enough to contaminate soil sediments, and then enter surface waters in runoff, causing contaminations in various major rivers in Thailand (Kruawal et al. 2005; Phewnil et al. 2012, 2010; Sangchan et al. 2014).

The contamination by atrazine on these rivers can directly affect the survival of photosynthetic aquatic organisms, because atrazine interferes with the electron transport chain in photosystem II by binding to the reaction center of the quinone B protein, which obstructs electron flow (Shukla \& Devine 2008; Trebst 2008). It is also known that atrazine can alter diversity of aquatic bacterioplankton communities by reducing presence of susceptible bacteria and increasing populations of atrazine degrading- and mineralizing-bacteria, which can use atrazine as a carbon and nitrogen source (Bohuss et al. 2005; Radosevich et al. 1995; Vargha et al. 2005). However, whether atrazine similarly impacts microbial communities associated with algal surfaces has been unknown. For this reason, 16S rDNA amplicon technology was used to compare the microbiota of Cladophora sp. treated with different atrazine concentrations $(0,12$, $60,300$, and $1000 \mu \mathrm{g} / \mathrm{L})$ to answer whether culturing of the host Cladophora affect its microbiota, and also to determine the effect of atrazine on the Cladophora microbiota.

\section{MATERIALS AND METHODS}

\section{ALGAL IDENTIFICATION}

A sample of a Cladophora was collected from Lumpini Park, Bangkok, Thailand (13.7314 $\left.{ }^{\circ} \mathrm{N}, 100.5414^{\circ} \mathrm{E}\right)$, and the alga was identified to genus level on distinctive microscopic features: Branching filaments, reticulate plastids, and relatively large cell size. A sample of the dried specimen has been deposited under barcode number BCU 5002 in the Kasin Suvatabandhu Herbarium, Department of Botany, Chulalongkorn University, Thailand (https://www.chula.ac.th/museum/763/). To perform the molecular identification, total DNA was extracted by using Thermo Scientific GeneJET Plant Genomic DNA Purification Kit (Thermo Scientific ${ }^{\text {TM, }}$ USA), before amplification of $23 \mathrm{~S}$ ribosomal DNA (23S rDNA) was conducted using the methods described in Sherwood and Presting (2007). A PCR product of the expected size was sequenced using Sanger sequencing (Macrogen, South Korea).

The $23 \mathrm{~S}$ rDNA sequence from the Bangkok Cladophora collection was deposited in Genbank under accession number MK863366. The phylogenetic analysis of this sequence and other Cladophora $23 \mathrm{~S}$ rDNA sequences (Genbank accession numbers AJ544728.1, AJ544752.1, AJ544753.1, AJ544754.1, AJ544755.1, AJ544756.1, AJ544757.1, AJ544760.1, AJ544761.1, AJ544763.1, AJ544764.1, KX421223.1, KX421224.1, KX421225.1, KX421226.1, KX421227.1, KX421228.1, KX421229.1, KX421230.1, KX421231.1, KX421232.1, KX421233.1, KX421234.1, MG021092.1, MG021094.1) was performed using a partial 23S rDNA sequence from Aegagropila linnaei (MF683076.1) as an outgroup. All sequences were aligned using MAFFT alignment v 7.402 (Katoh et al. 2009) and tested for evolutionary model using jModelTest2 v 2.1.6 (Darriba et al. 2012), before performing Maximum-Likelihood analysis using RAxML v 8.2.12 (Stamatakis 2014) and Bayesian analysis using MBayes v 3.2.7a (Ronquist et al. 2012) available on the CIPRES XSEDE Portal (Miller et al. 2012) using a TrN $+\mathrm{G}$ substitution model. Four independent chains were run for $1,000,000$ cycles and consensus topologies calculated after 25,000 burn-in cycles.

\section{BACTERIAL MICROBIOTA OF Cladophora sp.}

The 16S rDNA amplicons were employed to infer the taxonomic diversity of bacterial microbiota of Cladophora 
of the same morphological type for which $23 \mathrm{~S}$ rDNA sequence had been obtained. Firstly, the algal biomass was well-washed with Bold's Basal Medium to remove debris. Then, total metagenomic DNA was extracted using Quick-DNA Fecal/Soil Microbe Kits (Zymo Research, Carolina Biological Supply, Burlington, NC, USA), from three samples to generate three technical replicates. DNA was sent to Omics Science and Bioinformatics Center, Faculty of Science, Chulalongkorn University for V3-V4 16S rDNA amplification and sequencing. Raw data were analyzed using QIIME2 v 2017.12.0 pipeline (Bolyen et al. 2019). The taxonomy of the assembled contigs was assigned using the SILVA 132 reference database (Quast et al. 2013) at $97 \%$ minimum similarity. To compare the presence of the taxa, the taxon was called 'present' if it was present in at least one replication of the data, otherwise, it was called 'absent'. Then, to find the core and environmental bacterial taxa, the bacterial taxa identified in this study was compared with those previously reported studies. The core bacterial taxa were bacteria co-presented in this study and previously reported studies from the north of U.S.A. meanwhile, the environmental bacterial taxa were bacteria present in this study but have not been reported anywhere else.

\section{EFFECTS OF THE HERBICIDE ATRAZINE ON MICROBIOTA OF Cladophora sp. IN LABORATORY CULTURE}

To investigate the effect of atrazine on microbiota of cultured Cladophora sp., the field-collected Cladophora was rinsed with Bold's Basal Medium until all debris was removed. Then, the alga was cultivated in Bold's Basal Medium for seven days before treating replicate algal cultures with five atrazine concentrations, including $0,12,60,300$, and $1,000 \mu \mathrm{g} / \mathrm{L}$. The algal cultures were maintained with 16:8 daily light: dark cycle at room temperature. Total DNA was extracted on day 0 and day 14 . Total metagenomic DNA was extracted by the same method described for the 23S rDNA-characterization of the Cladophora. Then, the level of taxonomic richness was compared between each experimental set using the non-parametric Kruskal-Wallis test with the Shannon index $(\mathrm{H})$ as the dependent variable. The raw data for $16 \mathrm{~S}$ rDNA amplicon analysis for field-collected and cultured Cladophora were deposited in the NCBI Short Read Archive accession number SAMN13351969.

\section{RESULTS}

\section{ALGAL IDENTIFICATION}

Morphological observation suggested that the alga belonged to genus Cladophora (Figure 1). Phylogenetic analysis of $23 \mathrm{~S}$ rDNA analyzed using maximum likelihood and Bayesian frameworks (Figure 2) suggested that the Cladophora used in this study was closely related to an unclassified Cladophora isolate obtained from Northern California freshwater aquatic ecosystems (NCBI accession number MG021094).

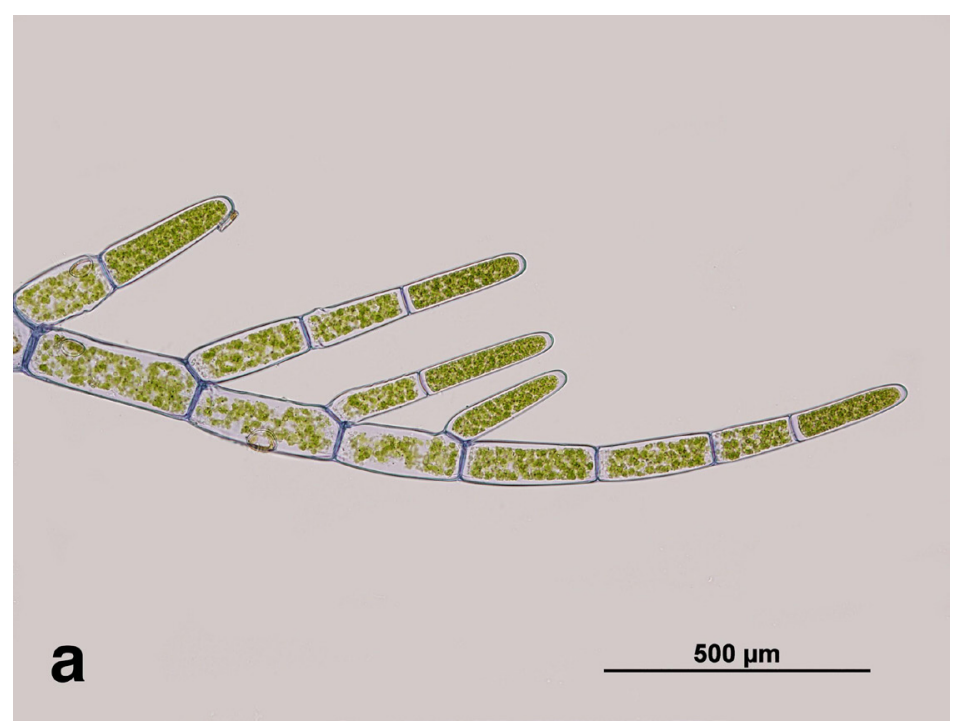




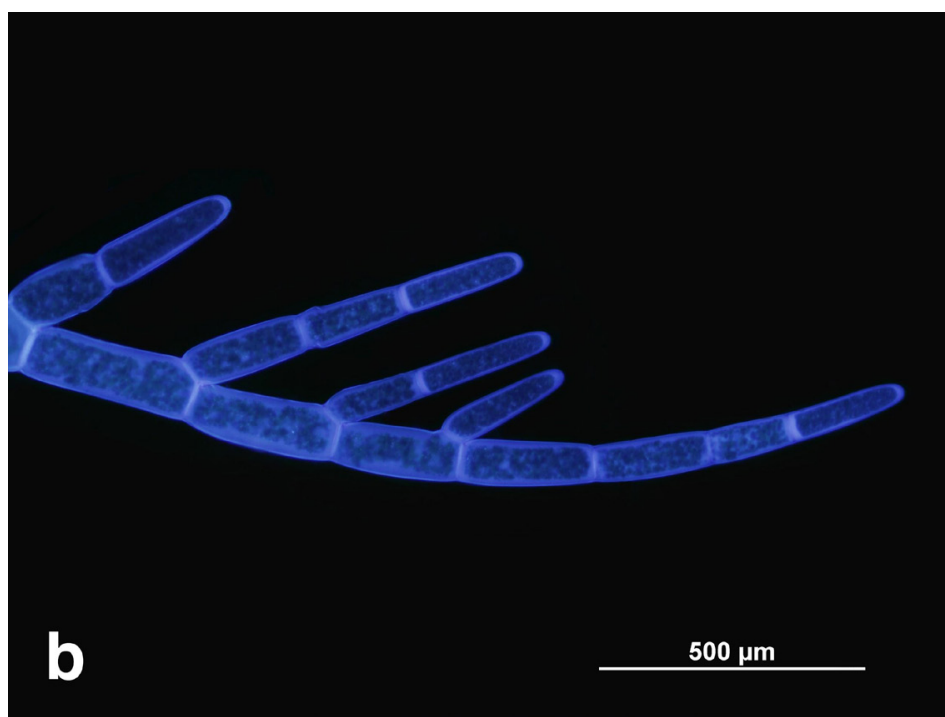

FIGURE 1. The morphology of (a) Cladophora sp. observed under light microscopy and (b) Cladophora sp. stained with Calcofluor White observed under fluorescence microscopy. The branching of the filament that was located close to the cross wall is the unique character of algae genus Cladophora

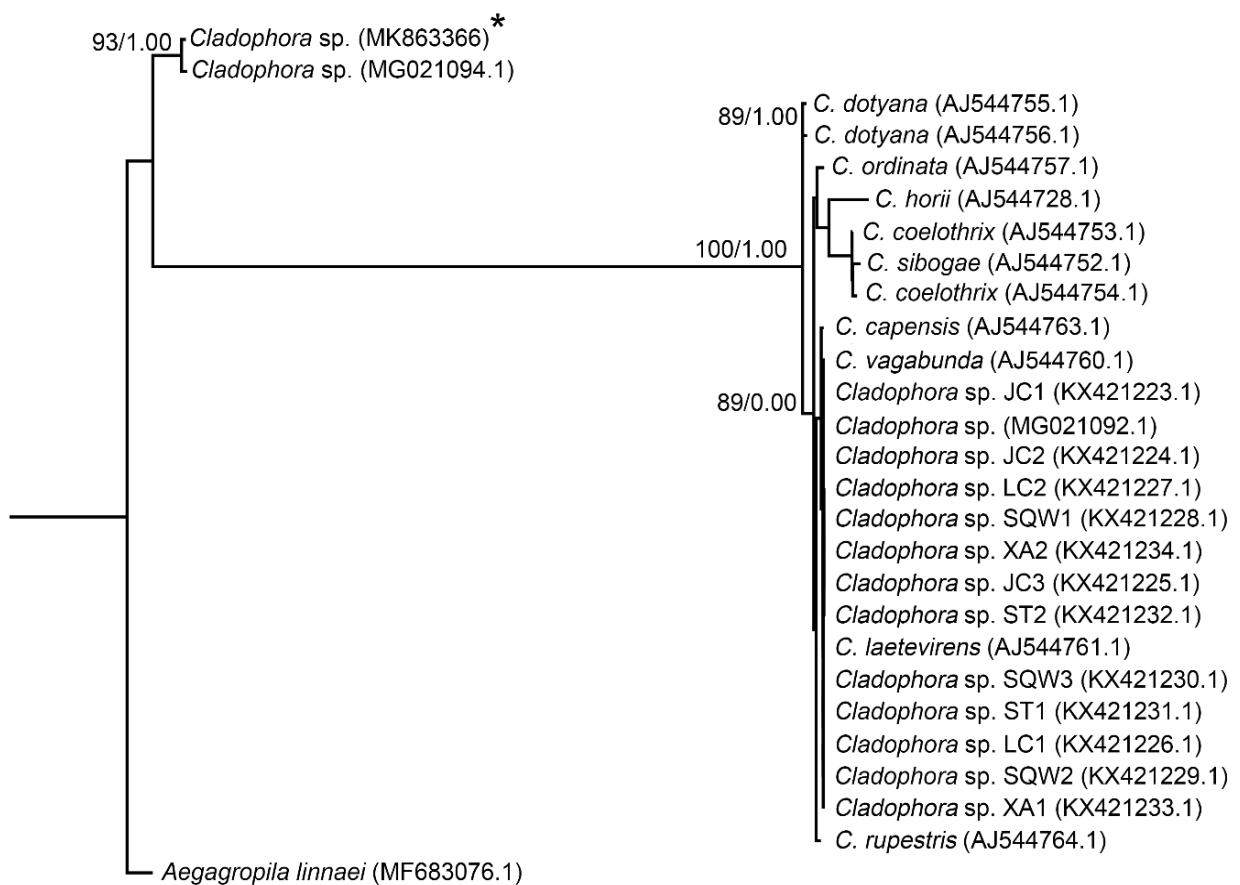

0.5

FIGURE 2. Maximum-Likelihood tree inferred from 23S rDNA of Cladophora species. The associated NCBI accession numbers were Maximum-Likelihood bootstrap values and Bayesian posterior probability values are shown at the respective nodes. The scale bar represents the estimated number of nucleotide substitutions per site. The closely related green alga Aegagropila linnaei was used as the outgroup 


\section{S rDNA AMPLICON ANALYSIS}

Our results from 16S rDNA amplicon analysis suggested that the microbiota included at least 106 possible OTUs representing 12 bacterial phyla which are Acidobacteria, Actinobacteria, Armatimonadetes, Chloroflexi, Cyanobacteria, Deinococcus-Thermus, Epsilonbacteraeota, Nitrospirae, Patescibacteria, Planctomycetes, Proteobacteria, WPS-2, and unknown bacterial phyla which consisted of 68 known bacterial genera (Figure 3).

The five most dominant bacterial phyla associated with the field-collected alga were Proteobacteria (36.77\%), Acidobacteria (23.90\%), Cyanobacteria $(14.70 \%)$, Planctomycetes (6.67\%), and Chloroflexi $(6.35 \%)$. At the genus level, the five most dominant genera were Acidobacteria aridibacter (17.32\%), uncultured Proteobacteria belonging to Rhizobiaceae (5.35\%), uncultured Chloroflexi belonging to Caldilineaceae (3.96\%), uncultured Proteobacteria belonging to Rhizobiales incertae Sedis (3.82\%), and uncultured Cyanobacteria belonging to SepB-3 (3.72\%).

To investigate the effect of laboratory culturing on the algal microbiota, we compared the microbiota of cultured Cladophora treated with different concentrations of atrazine. The results showed that after maintaining the algal culture in the laboratory for two weeks, the five most dominant phyla remained the same but with different taxonomic richness - Cyanobacteria (55.96\%), Proteobacteria (20.59\%), Chloroflexi (9.67\%), Planctomycetes (5.21\%), and Acidobacteria $(4.40 \%)$. Hence, an increase of Cyanobacteria and Armatimonadetes and a decrease of Proteobacteria, Acidobacteria, Planctomycetes, Chloroflexi, Actinobacteria, Patescibacteria, Deinococcus-Thermus, Epsilonbacteraeota, WPS-2, and Nitrospirae were observed. Both WPS-2 and Nitrospirae were completely disappeared from the control (non-atrazine) treatment cultures.

The five most-dominant genera associated with non-atrazine cultured Cladophora were uncultured Cyanobacteria belonging to Leptolyngbyaceae (41.62\%), uncultured Chloroflexi belonging to Caldilineaceae (6.88\%), uncultured Proteobacteria belonging to A0839 (6.16\%), uncultured Planctomycetes belonging to Gemmataceae (3.39\%), and uncultured Proteobacteria belonging to Reyranellaceae (3.27\%). Additionally, some bacterial genera were absent from the non-atrazine cultured Cladophora. These included Actinobacteria gordonia, Planctomycetes planctomicrobium and AKYG587, and Proteobacteria azospirillum, Pseudaminobacter, Sphingoaurantiacus, and Tabrizicola.

Then, we compared the Cladophora microbiota from each atrazine treatment. The results showed that after two weeks of treatment using different concentrations of atrazine, the five most dominant bacterial phyla remained almost the same, however, with different taxonomic richness. The five most dominant bacterial phyla in $12 \mu \mathrm{g} / \mathrm{L}$ atrazine were Cyanobacteria (34.75\%), Proteobacteria (24.39\%), Acidobacteria (16.71\%), Chloroflexi (10.65\%), and Planctomycetes $(4.95 \%)$. The five most dominant bacterial phyla in $60 \mu \mathrm{g} / \mathrm{L}$ atrazine were Acidobacteria (39.95), Proteobacteria (28.30\%), Chloroflexi (14.24\%), Cyanobacteria (6.51\%), and Planctomycetes (4.29\%). The five most dominant bacterial phyla in $300 \mu \mathrm{g} / \mathrm{L}$ atrazine were Chloroflexi (22.06\%), Proteobacteria (19.05\%), Acidobacteria (16.26\%), Patescibacteria (11.75\%), and Planctomycetes $(9.47 \%)$. The five most dominant bacterial phyla in $1000 \mu \mathrm{g} / \mathrm{L}$ atrazine were Acidobacteria (47.92\%), Proteobacteria (21.51\%), Chloroflexi (9.16\%), Planctomycetes (6.30\%), and Actinobacteria (5.36\%).

A reduction of some bacterial genera was observed when the concentration of atrazine is increased. Proteobacteria (Dongia and Amphiplicatus) and Cyanobacteria (Acaryochloris, Chamaesiphon, and Scytonema) found in the control treatment were absent from the algal cultures treated with 60, 300, and $1000 \mu \mathrm{g} / \mathrm{L}$ atrazine. Meanwhile, Cyanobacteria planoglabratella, Pleurocapsa, Schizothrix, and Xenococcus, and Acidobacteria aridibacter were absent from the algal cultures treated with 300 and $1000 \mu \mathrm{g} / \mathrm{L}$ atrazine. From the algal cultures treated with $1000 \mu \mathrm{g} / \mathrm{L}$ atrazine, Proteobacteria phreatobacter, Planctomycetes and Telmatocola, Acidobacteria blastocatella, and Cyanobacteria leptolyngbya were absent. However, most of the bacterial genera present in the control were present in most of atrazine concentrations.

Statistical comparisons suggested that the diversity level present in the algal microbiota before the experimental atrazine treatment was the highest and the diversity level of the algal microbiota in the $12 \mu \mathrm{g} / \mathrm{L}$ atrazine treatment was the lowest. However, we did not observe a significant difference of the bacterial diversity level among the field-collected and the atrazine treated Cladophora. 


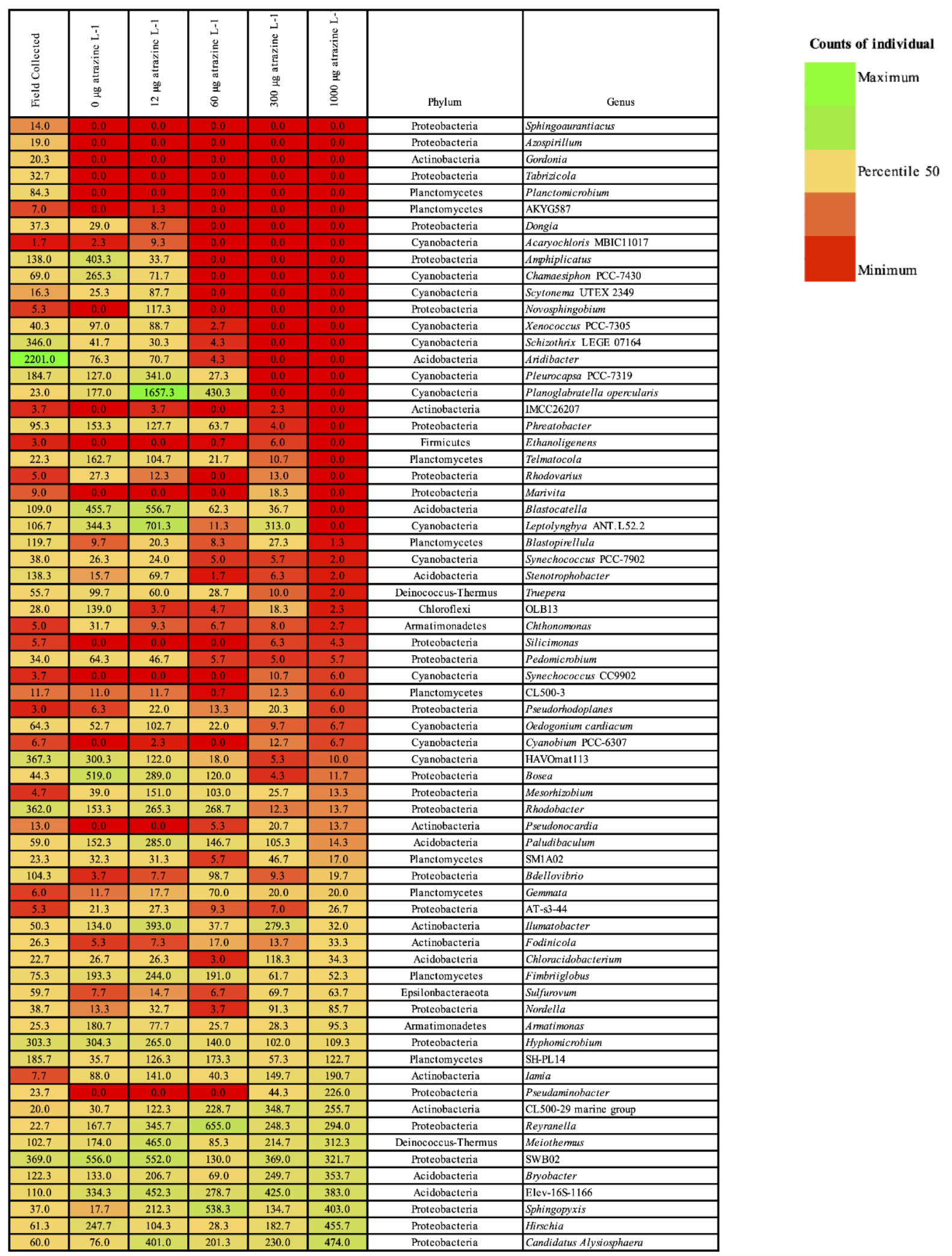

FIGURE 3. Known bacterial taxa present in field-collected Cladophora, cultured Cladophora, and atrazine-treated cultured Cladophora. The numbers and colors in the box represent the counts and percentile of the counts of individuals in each taxon 


\section{DISCUSSION}

\section{CORE MICROBIOME AND ENVIRONMENTAL OF FIELD-} COLLECTED Cladophora

This is the first study of the microbiota of the green alga Cladophora in Thailand. We identified an isolate from northern Thailand and studied its microbiota before and after treatments of atrazine, an herbicide widely used in agriculture. Studies showed that specific phylogenetic groups of heterotrophic bacteria occur in close association with specific green algae as the algae provides organic exudates for bacteria. Therefore, it is hypothesized that these bacteria might play important roles in survival and dispersal of organisms.

Among the thirteen bacterial phyla identified in the field-collected Cladophora (Acidobacteria, Actinobacteria, Armatimonadetes, Chloroflexi, Cyanobacteria, Deinococcus-Thermus, Epsilonbacteraeota, Nitrospirae, Patescibacteria, Planctomycetes, Proteobacteria, and WPS-2), we found some bacterial phyla present in common with the Cladophora microbiomes previously reported from the north of U.S.A. (Braus et al. 2017; Graham et al. 2015; Zulkifly et al. 2012). These included Acidobacteria bryobacter, Actinobacteria ilumatobacter, Armatimonadetes armatimonas, Cyanobacterial chamaesiphon, Deinococcus-Thermus truepera and Meiothermus, Planctomycetes gemmata and Proteobacteria rhodobacter, Bdellovibrio, Hyphomicrobium, Novosphingobium, and Sphingopyxis.

These bacterial genera, i.e. Acidobacteria bryobacter, Planctomycetes gemmata, and Proteobacteria novosphingobium were also present in a close association with other green algae and early diverging land plants. For example, Acidobacteria bryobacter was reported as a closely associated taxon of a chlorophyte alga Chlorella sorokiniana (Lebrero et al. 2016), a streptophyte alga Chara braunii (Saltykova 2015), and a liverwort Marchantia sp. (Alcaraz et al. 2018). Planctomycetes gemmata was present in the microbiome of a chlorophyte alga Ulva sp. in Carreço, Portugal (Lage \& Bondoso 2011; Faria et al. 2018) and a streptophyte alga Chara braunii in Japan (Saltykova 2015). Novosphingobium is known as Plant Growth Promoting Bacteria (PGPB) in a green alga Nannochloris sp. (Ramanan et al. 2015). However, their functions in the algal microbiomes have not yet been elucidated.

Actinobacteria Ilumatobacter, Armatimonadetes Armatimonas, Cyanobacterial Chamaesiphon, Deinococcus-Thermus Truepera and Meiothermus, and Proteobacteria rhodobacter, Bdellovibrio, Hyphomicrobium, and Sphingopyxis have not been reported from microbiome of green algae other than
Cladophora. However, these bacterial genera were always present in the local environmental samples together with green algal species. For example, the Actinobacteria ilumatobacter was present in the co-occurrence networks among bacteria and microbial eukaryotes of Lake Baikal during a Spring phytoplankton bloom (Mikhailov et al. 2019) and in a eutrophic lake in South Norway (Parulekar et al. 2017). The presence of these bacteria suggested their essential functions for the survival of other photosynthetic phytoplankton in the system.

Some bacterial phyla previously reported in microbiota of temperate U.S.A. Cladophora were not present in our results. These included the bacterial phyla Bacteroidetes, Verrucomicrobiae, Lentisphaerae, Nitrospirae, and Fusobacteria (Braus et al. 2017; Graham et al. 2015; Zulkifly et al. 2012). This incongruence suggested that these bacteria might be environmentally specific and might not be required for growth and dispersal of Cladophora in tropical regions like Thailand. However, this does not mean that the functions performed by these bacteria were not essential. It could be that the functions provided by these bacteria were substituted by those performed by other local bacterial taxa observed in this study.

Additionally, some human pathogenic bacteria such as Campylobacter, Escherichia, Salmonella, and Plesiomonas previously reported from Cladophora in Lake Michigan (Byappanahalli et al. 2009, 2007, 2003; Chun et al. 2013; Ishii et al. 2006; Olapade et al. 2006; Whitman et al. 2003) were not present in the results from this study. This suggested that these pathogenic bacteria are not evolutionarily important for the growth of Cladophora and the presence of these pathogens in living and dead Cladophora from Lake Michigan were environmentally influenced.

\section{EFFECTS OF LABORATORY CULTURING AND ATRAZINE ON THE MICROBIOTA OF Cladophora}

Comparison of the bacterial genera from field-collected and cultured Cladophora not treated with atrazine revealed the absence of 13 bacterial genera in the cultured Cladophora. These included Actinobacteria gordonia, Pseudonocardia, and IMCC26207, Cyanobacteria cyanobium PCC-6307 and Synechococcus CC9902, Planctomycetes planctomicrobium and AKYG587, and Proteobacteria azospirillum, Marivita, Novosphingobium, Pseudaminobacter, Sphingoaurantiacus, and Tabrizicola. The absence of these bacterial genera suggested that they were not essential for the survival of Cladophora when the nutrients, light, and temperature were suitable for algal growth or these bacteria genera were out-competed in such conditions. 


\section{EFFECTS OF DIFFERENT ATRAZINE CONCENTRATIONS ON THE MICROBIOTA OF Cladophora}

After two weeks of atrazine treatment, we observed that different atrazine concentrations differently affected the microbiota of Cladophora. By comparing the presence of bacterial taxa in different atrazine concentrations, these bacteria were categorized into three groups.

The first group consisted of bacteria that confers different degrees of susceptibility to atrazine. Certain bacterial genera - Acidobacteria aridibacter and Blastocatella, Cyanobacteria acaryochloris, Chamaesiphon, Leptolyngbya, Planoglabratella, Pleurocapsa, Schizothrix, Scytonema, and Xenococcus, Proteobacteria amphiplicatus, Dongia, Phreatobacter, and Planctomycetes telmatocola - were absent from the algal microbiota in certain concentrations of atrazine and in all other treatments with higher atrazine concentration. The absence of these bacteria was not phylum-specific, therefore, we hypothesized that the susceptibility of these bacteria might be taxa-dependent resulted from their intrinsic factor, for example, the presence of genes involved in atrazine metabolism.

Another group consisted of bacterial genera that were randomly present in several atrazine treatments. These included Actinobacteria IMCC26207 and Pseudonocardia, Cyanobacteria cyanobium PCC6307, Synechococcus PCC-7902, and Synechococcus CC9902, Planctomycetes blastopirellula, Proteobacteria rhodovarius, Marivita, Silicimonas, and Pseudaminobacter. Lastly, most of the bacterial taxa were present in all conditions used in this study: Field-collected, cultured, and atrazine-treated cultured Cladophora. These included several bacterial taxa from phyla Acidobacteria, Actinobacteria, Armatimonadetes, Chloroflexi, Cyanobacteria, Deinococcus-Thermus, Epsilonbacteraeota, Planctomycetes, and Proteobacteria. Different bacterial taxa present under these conditions suggested that different degrees of adaptive ability were adopted by these bacteria to cope with the herbicide atrazine, as we observed both increases and decreases in their population when the concentration of atrazine was increased.

This increase and decrease of the bacterial taxonomic diversity (although not statistically different) and its change in richness suggested that these bacteria had the potential to adapt to the new environment when atrazine is present. In this study, the presence of atrazine did not involve only the addition of the chemical in the algal medium, but also changes that possibly occurred due to its effects. For example, the presence of this chemical caused a decline of highly atrazine-susceptible bacteria genera, which later decayed and became an organic resource for other surviving bacterial groups. Also, this chemical might alter the secretion of organic compounds of Cladophora or other associated organisms, which benefited certain bacterial groups.

Some of the bacterial taxa present in the atrazinetreated cultured Cladophora have previously been reported from atrazine contaminated environments. These included Actinobacteria gordonia (Drzyzga 2012) and Pseudonocardia (Desitti et al. 2017), Cyanobacteria schizothrix (Sugiura 2009) and Synechococcus (Weiner et al. 2007), Deinococcus-Thermus truepera (Fang et al. 2018), and Proteobacteria azospirillum (Gadkari 1991), Bdellovibrio (Liao et al. 2015), Bosea (Udiković-Kolić et al. 2012), Dongia (Wallace \& May 2018), Hyphomicrobium (Liu et al. 2019), Mesorhizobium (Drouin et al. 2010), Novosphingobium (Sohn et al. 2004), Pedomicrobium (Satsuma 2009), Phreatobacter (Tóth et al. 2014), Pseudaminobacter (Topp et al. 2000), Pseudorhodoplanes (Esquirol et al. 2018), Rhodobacter (Zhang et al. 2012), and Sphingopyxis (Chen et al. 2015). The presence of these bacterial taxa in atrazine contaminated conditions might due to their intrinsic ability to cope with the chemical. For example, these bacteria present in atrazine-treated cultured might have acquired genes involved in atrazine metabolism through horizontal gene transfer. The atzABC genes which involved in atrazine metabolism were conserved, widely spread, and could be obtained by means of lateral gene transfer (De Souza et al. 1998; Devers et al. 2005; Marri et al. 2007; Ochman et al. 2000; Vos et al. 2015).

\section{CONCLUSION}

This is the first study that investigated the Cladophora microbiome in Thailand. We observed that different atrazine concentrations affected the algal microbiomes both in their taxonomic composition and the species richness. Comparisons between microbiomes of Cladophora present in Thailand and the U.S.A indicated that some bacteria, i.e. Acidobacteria, Actinobacteria, Armatimonadetes, Chloroflexi, Cyanobacteria, Deinococcus-Thermus, Epsilonbacteraeota, Nitrospirae, Patescibacteria, Planctomycetes, Proteobacteria, and WPS-2 were present in all Cladophora samples suggesting that these bacteria might be crucial for Cladophora growth and survival. They might represent the core Cladophora microbiome that could result in the algal successful worldwide distribution.

\section{ACKNOWLEDGEMENTS}

This work was supported by the Center of Excellence on Hazardous Substance Management, Chulalongkorn University, Grant No. HSM-PJ-CT-18-04. We thank Dr. Panaya Kotchaplai for helping with the experimental setup. 


\section{REFERENCES}

Alcaraz, L.D., Peimbert, M., Barajas, H.R., DorantesAcosta, A.E., Bowman, J.L. \& Arteaga-Vázquez, M.A. 2018. Marchantia liverworts as a proxy to plants' basal microbiomes. Scientific Reports 8(1): 12712.

Bohuss, I., Rékasi, T., Szikora, S., Barkács, K., Záray, G. \& Ács, É. 2005. Interaction of acetochlor and atrazine with natural freshwater biofilms grown on polycarbonate substrate in Lake Velence (Hungary). Microchemical Journal 79: 201205.

Bolyen, E., Rideout, J.R., Dillon, M.R., Bokulich, N.A., Abnet, C.C., Al-Ghalith, G.A., Alexander, H., Alm, E.J., Arumugam, M., Asnicar, F. \& Bai, Y. 2019. Reproducible, interactive, scalable and extensible microbiome data science using QIIME 2. Nature Biotechnology 37(8): 852-857.

Braus, M.J., Graham, L.E. \& Whitman, T.L. 2017. Spatiotemporal dynamics of the bacterial microbiota on lacustrine Cladophora glomerata (Chlorophyta). Journal of Phycology 53(6): 1255-1262.

Byappanahalli, M.N., Sawdey, R., Ishii, S., Shively, D.A., Ferguson, J.A., Whitman, R.L. \& Sadowsky, M.J. 2009. Seasonal stability of Cladophora-associated Salmonella in Lake Michigan watersheds. Water Research 43(3): 806-814.

Byappanahalli, M.N., Whitman, R.L., Shively, D.A., Ferguson, J., Ishii, S. \& Sadowsky, M.J. 2007. Population structure of Cladophora-borne Escherichia coli in nearshore water of Lake Michigan. Water Research 41(16): 3649-3654.

Byappanahalli, M.N., Shively, D.A., Nevers, M.B., Sadowsky, M.J. \& Whitman, R.L. 2003. Growth and survival of Escherichia coli and enterococci populations in the macroalga Cladophora (Chlorophyta). FEMS Microbiology Ecology 46(2): 203-211.

Chen, Q., Yang, B., Wang, H., He, F., Gao, Y. \& Scheel, R.A. 2015. Soil microbial community toxic response to atrazine and its residues under atrazine and lead contamination. Environmental Science and Pollution Research 22(2): 9961007.

Chun, C.L., Ochsner, U., Byappanahalli, M.N., Whitman, R.L., Tepp, W.H., Lin, G., Johnson, E.A., Peller, J. \& Sadowsky, M.J. 2013. Association of toxin-producing Clostridium botulinum with the macroalga Cladophora in the Great Lakes. Environmental Science and Technology 47(6): 25872594.

Darriba, D., Taboada, G.L., Doallo, R. \& Posada, D. 2012. jModelTest 2: More models, new heuristics and parallel computing. Nature Methods 9(8): 772.

De Souza, M.L., Seffernick, J., Martinez, B., Sadowsky, M.J. \& Wackett, L.P. 1998. The atrazine catabolism genes atzABC are widespread and highly conserved. Journal of Bacteriology 180(7): 1951-1954.

Department of Agriculture. 2019. Registered Hazardous Substance. Department of Agriculture, Ministry of Agriculture and Cooperatives. Accessed on 18 December 2019.

Desitti, C., Beliavski, M., Tarre, S. \& Green, M. 2017. Stability of a mixed microbial population in a biological reactor during long term atrazine degradation under carbon limiting conditions. International Biodeterioration and Biodegradation 123: 311-319.

Devers, M., Henry, S., Hartmann, A. \& Martin-Laurent, F. 2005. Horizontal gene transfer of atrazine-degrading genes (atz) from Agrobacterium tumefaciens St96-4 pADP1: Tn5 to bacteria of maize-cultivated soil. Pest Management Science: Formerly Pesticide Science 61(9): 870-880.

Drouin, P., Sellami, M., Prévost, D., Fortin, J. \& Antoun, H. 2010. Tolerance to agricultural pesticides of strains belonging to four genera of Rhizobiaceae. Journal of Environmental Science and Health Part B 45(8): 757 765.

Drzyzga, O. 2012. The strengths and weaknesses of Gordonia: A review of an emerging genus with increasing biotechnological potential. Critical Reviews in Microbiology 38(4): 300-316.

EPA 2003. Interim Reregistration Eligibility Decision for Atrazine. Washington: U.S. Environmental Protection Agency (EPA).

Esquirol, L., Peat, T.S., Wilding, M., Hartley, C.J., Newman, J. \& Scott, C. 2018. A novel decarboxylating amidohydrolase involved in avoiding metabolic dead ends during cyanuric acid catabolism in Pseudomonas sp. strain ADP. PLoS ONE 13(11): e0206949.

Fang, H., Zhang, H., Han, L., Mei, J., Ge, Q., Long, Z. \& Yu, Y. 2018. Exploring bacterial communities and biodegradation genes in activated sludge from pesticide wastewater treatment plants via metagenomic analysis. Environmental Pollution 243: 1206-1216.

Faria, M., Bordin, N., Kizina, J., Harder, J., Devos, D. \& Lage, O.M. 2018. Planctomycetes attached to algal surfaces: Insight into their genomes. Genomics 110(5): 231-238.

Gadkari, D. 1991. Conjugation between two Escherichia coli strains and between Escherichia coli (donor) and Azospirillum brasilense (recipient) in the presence of various herbicides. Toxicological and Environmental Chemistry 30(3-4): 211-217.

Graham, L.E., Knack, J.J., Graham, M.E., Graham, J.M. \& Zulkifly, S. 2015. A metagenome for lacustrine Cladophora (Cladophorales) reveals remarkable diversity of eukaryotic epibionts and genes relevant to materials cycling. Journal of Phycology 51(3): 408-418.

Ishii, S., Yan, T., Shively, D.A., Byappanahalli, M.N., Whitman, R.L. \& Sadowsky, M.J. 2006. Cladophora (Chlorophyta) spp. harbor human bacterial pathogens in nearshore water of Lake Michigan. Applied and Environmental Microbiology 72(7): 4545-4553.

Katoh, K., Asimenos, G. \& Toh, H. 2009. Multiple alignment of DNA sequences with MAFFT. D. Posada. In Bioinformatics for DNA Sequence Analysis, New Jersey: Humana Press. pp. 39-64.

Kruawal, K., Sacher, F., Werner, A., Müller, J. \& Knepper, T.P. 2005. Chemical water quality in Thailand and its impacts on the drinking water production in Thailand. Science of The Total Environment 340(1-3): 57-70. 
Lage, O.M. \& Bondoso, J. 2011. Planctomycetes diversity associated with macroalgae. FEMS Microbiology Ecology 78(2): 366-375.

Laungsuwon, R. \& Chulalaksananukul, W. 2013. Antioxidant and anticancer activities of freshwater green algae, Cladophora glomerata and Microspora floccosa, from Nan River in northern Thailand. Maejo International Journal of Science and Technology 7(2): 181-188.

Lebrero, R., Ángeles, R., Pérez, R. \& Muñoz, R. 2016. Toluene biodegradation in an algal-bacterial airlift photobioreactor: Influence of the biomass concentration and of the presence of an organic phase. Journal of Environmental Management 183: $585-593$

Liao, X., Chen, C., Zhang, J., Dai, Y., Zhang, X. \& Xie, S. 2015. Operational performance, biomass and microbial community structure: Impacts of backwashing on drinking water biofilter. Environmental Science and Pollution Research 22(1): 546-554.

Liu, X., Chen, K., Chuang, S., Xu, X. \& Jiang, J. 2019. Shift in bacterial community structure drives different atrazinedegrading efficiencies. Frontiers in Microbiology 10: 88.

Marri, P.R., Hao, W. \& Golding, G.B. 2007. The role of laterally transferred genes in adaptive evolution. BMC Evolutionary Biology 7(1): S8.

Mikhailov, I.S., Zakharova, Y.R., Bukin, Y.S., Galachyants, Y.P., Petrova, D.P., Sakirko, M.V. \& Likhoshway, Y.V. 2019 Co-occurrence networks among bacteria and microbial eukaryotes of lake Baikal during a spring phytoplankton bloom. Microbial Ecology 77(1): 96-109.

Miller, M.A., Pfeiffer, W. \& Schwartz, T. 2012. The CIPRES science gateway: Enabling high-impact science for phylogenetics researchers with limited resources. In Proceedings of the $1^{\text {st }}$ Conference of the Extreme Science and Engineering Discovery Environment: Bridging from the eXtreme to the Campus and Beyond. pp. 1-8.

Ochman, H., Lawrence, J.G. \& Groisman, E.A. 2000. Lateral gene transfer and the nature of bacterial innovation. Nature 405: 299-304.

Olapade, O.A., Depas, M.M., Jensen, E.T. \& McLellan, S.L. 2006. Microbial communities and fecal indicator bacteria associated with Cladophora mats on beach sites along lake Michigan shores. Applied and Environmental Microbiology 72(3): 1932-1938.

Parulekar, N.N., Kolekar, P., Jenkins, A., Kleiven, S., Utkilen, H., Johansen, A., Sawant, S., Kulkarni-Kale, U., Kale, M. \& Sæbø, M. 2017. Characterization of bacterial community associated with phytoplankton bloom in a eutrophic lake in South Norway using 16S rRNA gene amplicon sequence analysis. PLoS ONE 12(3): e0173408.

Peerapornpisal, Y., Amornledpison, D., Rujjanawate, C., Ruangrit, K. \& Kanjanapothi, D. 2006. Two endemic species of macroalgae in Nan river, northern Thailand, as therapeutic agents. ScienceAsia 32(Supplement 1): 71-76.

Phewnil, O., Panichsakpatana, S., Tungkananuruk, N. \& Pitiyont, B. 2010. Atrazine transport from the maize (Zea mays L.) cultivated upland soil in Huay Kapo watershed, Nam Nao district, Phetchabun province, Thailand. Thai Journal of Agricultural Science 43(3): 119-127.

Phewnil, O., Tungkananurak, N., Panichsakpatana, S., Pitiyont, B., Siripat, N. \& Watanabe, H. 2012. The residues of atrazine herbicide in stream water and stream sediment in Huay Kapo watershed, Phetchabun province, Thailand. Environment and Natural Resources Journal 10(1): 42-52.

Quast, C., Pruesse, E., Yilmaz, P., Gerken, J., Schweer, T., Yarza, P., Peplies, J. \& Glöckner, F.O. 2013. The SILVA ribosomal RNA gene database project: Improved data processing and web-based tools. Nucleic Acids Research 41(D1): D590-D596.

Radosevich, M., Traina, S.J., Hao, Y.L. \& Tuovinen, O.H. 1995. Degradation and mineralization of atrazine by a soil bacterial isolate. Applied and Environmental Microbiology 61(1): 297-302.

Ramanan, R., Kang, Z., Kim, B.H., Cho, D.H., Jin, L., Oh, H.M. \& Kim, H.S. 2015. Phycosphere bacterial diversity in green algae reveals an apparent similarity across habitats. Algal Research 8: 140-144.

Ronquist, F., Teslenko, M., Van Der Mark, P., Ayres, D.L., Darling, A., Höhna, S., Larget, B., Liu, L., Suchard, M.A. \& Huelsenbeck, J.P. 2012. MrBayes 3.2: Efficient Bayesian phylogenetic inference and model choice across a large model space. Systematic Biology 61(3): 539-542.

Saltykova, A. 2015. Identifying prokaryotic consortia that live in close interaction with algae. Masters Thesis. Ghent: Ghent University (Unpublished).

Sangchan, W., Bannwarth, M., Ingwersen, J., Hugenschmidt, C., Schwadolrf, K. Thavornyutikarn, P., Pansombat, K. \& Streck, T. 2014. Monitoring and risk assessment of pesticides in a tropical river of an agricultural watershed in northern Thailand. Environmental Monitoring and Assessment 186(2): 1083-1099.

Satsuma, K. 2009. Complete biodegradation of atrazine by a microbial community isolated from a naturally derived river ecosystem (microcosm). Chemosphere 77(4): 590-596.

Sherwood, A.R. \& Presting, G.G. 2007. Universal primers amplify a $23 \mathrm{~S}$ rDNA plastid marker in eukaryotic algae and cyanobacteria. Journal of Phycology 43(3): 605-608.

Shukla, A. \& Devine, M.D. 2008. Basis of crop selectivity and weed resistance to triazine herbicides. In The Triazine Herbicides: 50 Years Revolutionizing Agriculture, edited by LeBaron, H.M., McFarland, J.E. \& Burnside, O.C. Oxford: Elsevier. pp. 111-118.

Sohn, J.H., Kwon, K.K., Kang, J.H., Jung, H.B. \& Kim, S.J. 2004. Novosphingobium pentaromativorans sp. nov., a high-molecular-mass polycyclic aromatic hydrocarbondegrading bacterium isolated from estuarine sediment. International Journal of Systematic and Evolutionary Microbiology 54(5): 1483-1487.

Stamatakis, A. 2014. RAxML version 8: A tool for phylogenetic analysis and post-analysis of large phylogenies. Bioinformatics 30(9): 1312-1313.

Sugiura, K. 2009. Effects of chemicals and metal ions on microcosms: Comparison of community metabolism to 
single-species responses to toxicants. Japanese Journal of Environmental Toxicology 12(1): 41-53.

Thiamdao, S., Boo, G.H., Boo, S.M. \& Peerapornpisal, Y., 2012. Diversity of edible Cladophora (Cladophorales, Chlorophyta) in northern and northeastern Thailand, based on morphology and nuclear ribosomal DNA sequences. Chiang Mai Journal of Science 39(2): 300-310.

Topp, E., Zhu, H., Nour, S.M., Houot, S., Lewis, M. \& Cuppels, D. 2000. Characterization of an atrazine-degrading Pseudaminobacter sp. isolated from Canadian and French agricultural soils. Applied and Environmental Microbiology 66(7): 2773-2782.

Tóth, E.M., Vengring, A., Homonnay, Z.G., Kéki, Z., Spröer, C., Borsodi, A.K., Márialigeti, K. \& Schumann, P. 2014. Phreatobacter oligotrophus gen. nov., sp. nov., an alphaproteobacterium isolated from ultrapure water of the water purification system of a power plant. International Journal of Systematic and Evolutionary Microbiology 64(3): 839-845.

Trebst, A. 2008. The mode of action of triazine herbicides in plants. In The Triazine Herbicides: 50 Years Revolutionizing Agriculture, edited by LeBaron, H.M., McFarland, J.E. \& Burnside, O.C. Oxford: Elsevier. pp. 101-110.

Udiković-Kolić, N., Scott, C. \& Martin-Laurent, F. 2012. Evolution of atrazine-degrading capabilities in the environment. Applied Microbiology and Biotechnology 96(5): 1175-1189

Vargha, M., Takáts, Z. \& Márialigeti, K. 2005. Degradation of atrazine in a laboratory scale model system with Danube river sediment. Water Research 39(8): 1560-1568.

Vos, M., Hesselman, M.C., te Beek, T.A., van Passel, M.W. \& Eyre-Walker, A. 2015. Rates of lateral gene transfer in prokaryotes: High but why? Trends in Microbiology 23(10): 598-605.

Wallace, J.G. \& May, G. 2018. Endophytes: The other maize genome. In The Maize Genome, edited by Bennetzen, J., Flint-Garcia, S, Hirsch, C., \& Tuberosa, R. Cham: Springer International. pp. 213-246.

Weiner, J.A., DeLorenzo, M.E. \& Fulton, M.H. 2007. Atrazine induced species-specific alterations in the subcellular content of microalgal cells. Pesticide Biochemistry and Physiology 87(1): 47-53

Whitman, R.L., Shively, D.A., Pawlik, H., Nevers, M.B. \& Byappanahalli, M.N. 2003. Occurrence of Escherichia coli and enterococci in Cladophora (Chlorophyta) in nearshore water and beach sand of Lake Michigan. Applied and Environmental Microbiology 69(8): 4714-4719.
Zhang, Y., Meng, D., Wang, Z., Guo, H., Wang, Y., Wang, X \& Dong, X. 2012. Oxidative stress response in atrazinedegrading bacteria exposed to atrazine. Journal of Hazardous Materials 229-230: 434-438.

Zulkifly, S., Graham, J.M., Young, E.B., Mayer, R.J., Piotrowski, M.J., Smith, I. \& Graham, L.E. 2013. The genus Cladophora Kützing (Ulvophyceae) as a globally distributed ecological engineer. Journal of Phycology 49: 1-17.

Zulkifly, S., Hanshew, A., Young, E.B., Lee, P., Graham, M.E., Graham, M.E., Piotrowski, M. \& Graham, L.E. 2012. The epiphytic microbiota of the globally widespread macroalga Cladophora glomerata (Chlorophyta, Cladophorales). American Journal of Botany 99(9): 1541-1552.

Anchittha Satjarak*

Plants of Thailand Research Unit

Department of Botany, Faculty of Science

Chulalongkorn University

10330 Bangkok

Thailand

Anchittha Satjarak*, Jittra Piapukiew, Wikrom Chanthapatchot \& Karnjana Ruen-Pham

Department of Botany, Faculty of Science

Chulalongkorn University

10330 Bangkok

Thailand

Jittra Piapukiew \& Alisa S. Vangnai

Biocatalyst and Environmental Biotechnology Research Unit

Faculty of Science

Chulalongkorn University

254 Phayathai Rd., Pathumwan

10330 Bangkok

Thailand

Alisa S. Vangnai

Department of Biochemistry, Faculty of Science

Chulalongkorn University

10330 Bangkok

Thailand

*Corresponding author; email: anchittha.s@chula.ac.th

Received: 15 April 2020

Accepted: 6 October 2020 